Case report

\title{
Percutaneous extraction of implantable cardioverter defibrillator electrode with mechanical dilator sheath
}

\author{
Hasan Güngör *, Cemil Zencir, Tarkan Tekten \\ Adnan Menderes University Department of Cardiology, Aydin, Turkey
}

\section{A R T I C L E I N F O}

\section{Article history:}

Received 4 January 2016

Received in revised form 20 January 2016

Accepted 21 January 2016

Available online 5 March 2016

Keywords:

Electrode

Extraction

Implantable Cardioverter defibrillator

Sheath

\begin{abstract}
A B S T R A C T
For removing the electrodes, manual simple traction may be useful and various methods have been used in extraction for chronically implanted electrodes. We report the case of successful percutaneous extraction of implantable cardioverter defibrillator electrode with Evolution mechanical dilator sheath.

(c) 2016 The Society of Cardiovascular Academy. Production and hosting by Elsevier B.V. All rights reserved. This is an open access article under the CC BY-NC-ND license (http://creativecommons.org/licenses/by-nc-nd/4.0/).
\end{abstract}

A 66-year-old man with ischemic cardiomyopathy who received a dual-chamber implantable cardioverter defibrillator (ICD) 7 years ago was referred to our hospital for the skin erosion causing protrusion of the lead portion secondary to infection. After detailed questioning, it was discovered that he had ICD pocket infection 3 years ago. ICD generator was removed and a new single-chamber ICD was implanted to contralateral pectoral region. Atrial and ventricular electrodes could not be removed due to fibrous adhesions at the contact points between electrodes and venous or cardiac walls. Proximal tips of these electrodes were fixed to the pectoral region. 2 months ago proximal tips of these electrodes were protruding after the skin erosion (Fig. 1).

Transvenous lead extraction procedure was performed in the cathlab under moderate sedation. After the skin dissection electrodes were separated from the scar tissue by blunt dissection. Atrial electrode was removed with manual traction. A locking stylet (Liberator Universal Locking Stylet, Cook Medical) and mechanical dilator sheath were used for ventricular lead. The Evolution mechanical dilator was positioned over the electrode. The dilator sheath was moved along the electrode body by cutting fibrous adhesion via the distal metal tip. Once the fibrous attachment is cut the outer sheath is advanced until another area of attachment is encountered. After the release of the electrode from fibrous tissue the electrode was pulled back into the sheath and removed (Figs. 2 and 3).

\footnotetext{
* Corresponding author at: Adnan Menderes University Faculty of Medicine, Department of Cardiology, 09100 Aydin, Turkey. Tel.: +90 5068892238 (mobile). E-mail address: drgungorhasan@yahoo.com (H. Güngör).

Peer review under responsibility of The Society of Cardiovascular Academy.
}

Electrodes of pacemaker or ICD usually undergo fibrotic encapsulation by activation of humoral and cellular immune response mechanisms after transvenous implantation. ${ }^{1}$ For removing these electrodes, manual simple traction may be useful, however chronically implanted electrodes develop fibrous attachments to surrounding structures and require more advanced extraction systems. ${ }^{2,3}$ Various methods have been used in electrode extraction including manual traction, extended weight or forcep-assisted traction, radiofrequency or laser devices, mechanical extraction systems, and open-chest surgery. ${ }^{3,4}$ The mechanical method with a hand-powered sheath marketed as the Evolution can

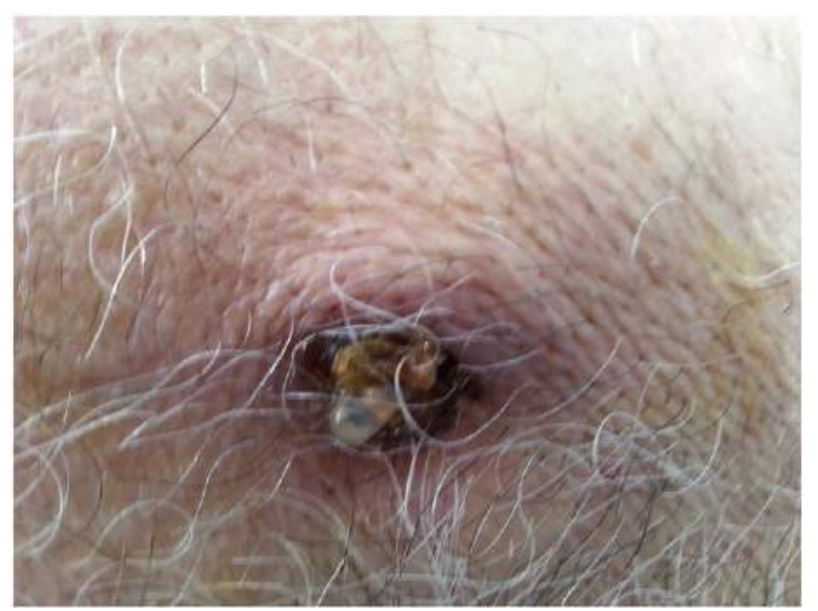

Fig. 1. Protrusion of the electrodes after skin erosion. 


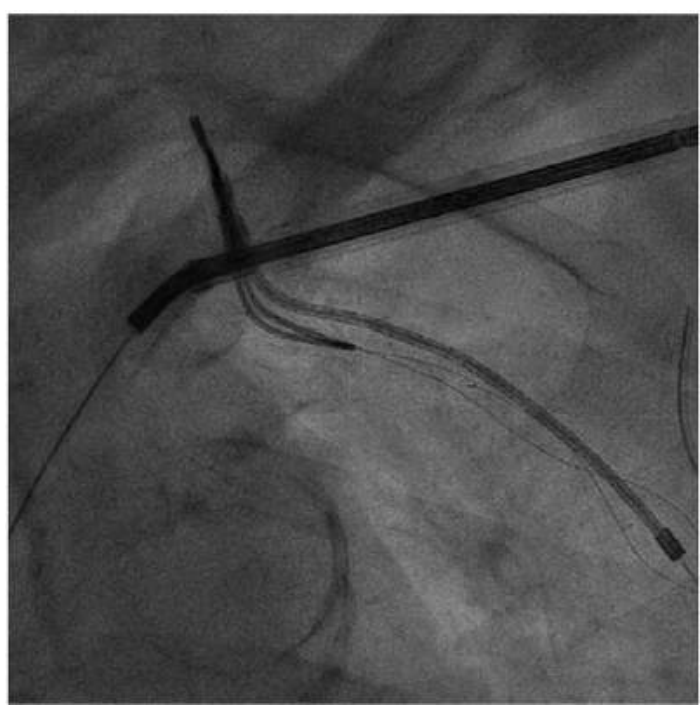

Fig. 2. Fluoroscopic view of the electrode covered by the Evolution sheath.

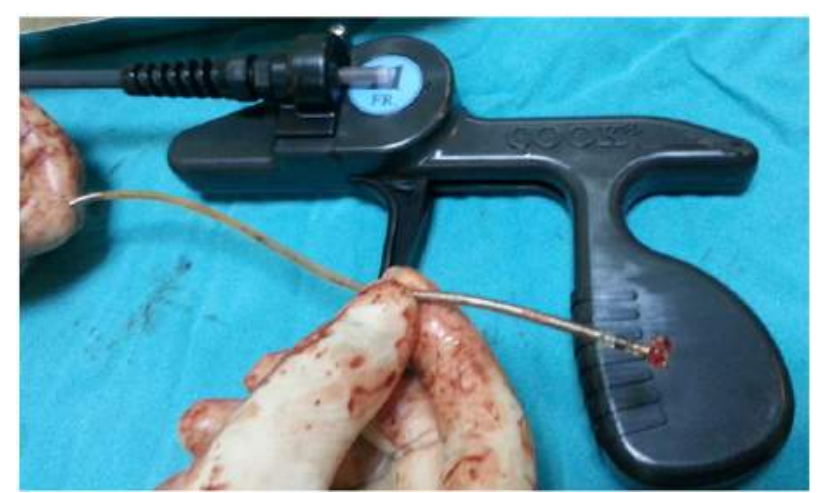

Fig. 3. Successfully extracted electrode. be used as a useful method for chronically implanted ICD electrodes in high risk patients.

\section{Conflict of interest}

None.

\section{References}

1. Esposito M, Kennergren C, Holmstrom N, Nilsson S, Eckerdal J, Thomsen P. Morphologic and immunohistochemical observations of tissues surrounding retrieved transvenous pacemaker leads. J Biomed Mater Res 2002;63:548-558.

2. Smith MC, Love CJ. Extraction of transvenous pacing and ICD leads. Pacing Clin Electrophysiol 2008;31:736-752.

3. Güngör H, Duygu H, Yildiz BS, Gül I, Zoghi M, Akin M. Excimer laser assisted implantable cardioverter defibrillator lead extraction: an alternative treatment to the surgery? Anadolu Kardiyol Derg 2009;9:340-341.

4. Oto A, Aytemir K, Yorgun $\mathrm{H}$, et al. Percutaneous extraction of cardiac pacemaker and implantable cardioverter defibrillator leads with evolution mechanical dilator sheath: a single-centre experience. Europace 2011;13:543-547. 